\title{
Saving the Tiger
}

\section{Guy Mountfort}

In Oryx, September 1972, Zafar Futehally described how, when it was found that the number of tigers in India had dropped to below 2000, Project Tiger was launched, with a Task Force appointed by Mrs Gandhi, and chaired by Dr Karan Singh, Minister of Tourism and Civil Aviation and of the Indian Wildlife Board; the World Wildlife Fund promised a million dollars if the Indian Government would take the necessary conservation measures, and the President, HRH Prince Bernhard, has launched an international campaign to raise the money. Tiger hunting had already been banned throughout India, Pakistan, Bangladesh, Nepal and Bhutan, and the US and Britain have banned the import of tiger skins-tigers are one of the five endangered cats covered by the fur trade's voluntary ban agreed in 1970. Last summer the Indian Government produced a very valuable 100-page report on the tiger situation, supported by detailed surveys and proposing the creation of eight tiger reserves based on existing sanctuaries. In this article Guy Mountfort who is a WWF Trustee, and has made a special study of the Indian wildlife situation, describes the proposed reserves and continues the story of what he calls 'the biggest and most important advance in the conservation of Asiatic wildlife'.

No-one reacted to the tiger situation more positively than the Prime Minister, Mrs Gandhi. She charged the Tiger Task Force with the immediate preparation of plans for the creation of tiger reserves. The report proposed that eight of the best existing wildlife sanctuaries where there were tigers should be enlarged and improved to become fully protected and scientifically managed reserves; a ninth reserve has since been added to the list. The cost, to be spread over the next six years, will be nearly $£ 3$ million. The WWF contribution will be spent on items of essential equipment requiring foreign currency, such as helicopters and two-way radio sets for controlling poaching.

Obviously, in protecting the tiger it is essential to protect its whole ecosystem. This means not only protecting the animals on which it preys, but also skilful management of their environment. The chosen reserves therefore provide protection for a representative cross-section of all Indian forest wildlife and vegetation, including other endangered species. By rigid control of poaching and the use of scientific wildlife management techniques, it is hoped gradually to build up populations of at least 100 tigers in each reserve.

Manas Wildlife Sanctuary in Assam, which it is proposed to enlarge to 2900 square kilometres, is a fine example of deciduous riverine forest, interspersed with evergreens and savanna, in the eastern foothills of the Himalayas bordering a protected area in Bhutan. 
There are about 40 tigers, large populations of wild boar, barking deer, hog deer, swamp deer and elephant and a few of the rare great Indian rhinoceroses. It is hoped to develop the reserve in collaboration with the Bhutan Government, as many of the larger animals move back and forth across the frontier.

Palamau National Park in Bihar-to be enlarged to $1500 \mathrm{sq} \mathrm{km}$ - is an undulating tract of the finest sal forest in the country, with an understorey of bamboo among grassy glades. It has 37 tigers, small populations of elephant, gaur, sambar, chital, nilgai, barking deer and wild boar, and a few wolves and leopards.

Simplipal National Park in Orissa, though not yet studied in detail, is regarded as ideal for development as a major tiger reserve. A rolling table-land of $300 \mathrm{sq} \mathrm{km}$ in the cool eastern peninsula, it combines sal forest tracts and savanna. The natural vegetation is a mixture of tropical semi-evergreen, moist deciduous and tropical dry deciduous, interspersed with perennial streams. Abundant wildlife includes tigers, leopards, sambar, chital, barking deer, wild boar and elephants.

The scenically superb Corbett National Park in Uttar Pradesh, 570 sq $\mathrm{km}$ of tropical deciduous forest and open grasslands among tracts of riverine khair and sissoo trees in the Siwalik Range of the Himalayan foothills, has long been famous for tigers; the new Ram Ganga dam has flooded some of the bottomland woods and grazing in the valleys, but is not expected seriously to affect the area for wildlife. In addition to about 30 tigers, there are leopards, crocodiles, gavials, Himalayan black bears, elephants, chital, sambar, barking deer and wild boar.

Ranthampore, in Rajasthan, in the undulating Vindhyas range, consists of a wildlife sanctuary of $155 \mathrm{sq} \mathrm{km}$ and a reserved forest of $300 \mathrm{sq} \mathrm{km}$; it will be enlarged by the inclusion of adjoining forests. In many ways this is one of the most attractive wildlife reserves in India with a balanced mixture of unexploited sal forest, bamboo stands and extensive grasslands, and one of the few places where tigers can be seen in daylight. Like Corbett, it is at present unapproachable by road in the rainy season. The last census listed 36 tigers, 40 leopards, 19 jungle cats, 26 sloth bears and numerous wild dogs, hyenas, jackals and foxes. With the additional new area, herbivores will include 550 gaur, 850 sambar, 7500 chital, 200 barking deer, 100 barasingha and more than a thousand wild boar.

Melghat, in Maharashtra, with 42 tigers and plenty of leopards, is a scenically beautiful area in the ghats (hill ranges) of the Satpuras, chiefly consisting of teak forest with an understorey of bamboo, both of which, unfortunately, because of their commercial value, will have to be exploited; this will be done with great care in relation to the wildlife management plan. The present small wildlife sanctuary at Dokna (352 sq km) is to be extended to include $900 \mathrm{sq} \mathrm{km}$ of reserved forest. A wildlife census is not yet available but there are 
known to be good populations of gaur, sambar, chital, barking deer and wild boar.

Bandipur, the smallest of the proposed tiger reserves, in the western ghats of Mysore State, consists of the $56-\mathrm{sq}-\mathrm{km}$ sanctuary plus 160 $\mathrm{sq} \mathrm{km}$ of reserved forest. Vegetation is chiefly open deciduous forest of teak and miscellaneous tree species, with abundant grass on the forest floor. There are at present 18 tigers, about 50 leopards, 700 chital, 250 sambar, 350 gaur and 200 elephants, many wild boar and a few barking deer. Though small, Bandipur has been selected because tigers have a long established preference for this range of forested hills; it may be enlarged later.

The Sunderbans of West Bengal is proposed for the ninth reserve, a wild region of saline mangrove swamps extending for $10,000 \mathrm{sq} \mathrm{km}$ across the delta of the Ganges, and famous for its tigers, which today prey chiefly on the numerous chital and wild boar. It is hoped that this new reserve will be adjacent to the existing Sunderbans reserve on the Bangladesh side.

In all the chosen areas wildlife is to be given precedence over forestry, with no timber extraction for at least six years, during which intensive research will be done. Tiger prey species will be maintained by careful habitat management and vigorous control of poaching, with fire towers at intervals and armed guards patrolling the boundaries. Some village settlements in the reserves will be moved, domestic cattle- a major problem in all India's 50 reserveswill be strictly controlled and wherever possible kept out; those allowed in will be inoculated against infectious diseases. A ban on all hunting will extend to a buffer zone $6 \mathrm{~km}$ in depth around the reserves. If the wild herbivorous populations in the reserves increase to a level which the available grazing cannot sustain, they will be culled under controlled conditions in the buffer zone, or surplus animals will be translocated to other reserves. Although initially the reserves will be managed entirely for the benefit of the wildlife, the intention is that ultimately they will become normal national parks with some access for controlled tourism. In view of the huge investment which the Indian Government is putting into this scheme, it is only fair that the potential for earning much-needed foreign currency should ultimately be expoited. But it is clear that the primary intention is to implement Mrs Gandhi's determination to prevent the extinction of the tiger and its prey species. And there is now little doubt that she will succeed. It is the biggest and most important advance yet seen in the conservation of Asiatic wildlife.

Nepal, Bhutan and Bangladesh are equally determined. It is believed that about 150 tigers still exist in Nepal, some in the Chitawan and Sukla Phanta reserves in the lowland terai. There are now good prospects that a third reserve will be created at Karnali, which has the highest tiger population, formerly a Royal Hunting Preserve of the late King Mahendra's before he became a conservationist; fortunately, his successor, King Birenda, is also greatly interested in preserving Nepal's wildlife. 
The little-known kingdom of Bhutan is thought to have about 200 tigers, many of them in the Manas reserve, which has a common boundary with the Manas Sanctuary in Assam. It will obviously be a great advantage if, as is planned, the two reserves can be managed in collaboration. WWF hopes shortly to conduct a survey of endangered animal species and habitats in Bhutan.

Bangladesh, in spite of its many social and economic problems, is already embarked on a programme of wildlife conservation. Within two days of becoming Prime Minister, Sheikh Mujibur Rahman issued a proclamation forbidding the killing of wild animals and the destruction of forests. The tiger was chosen as the 'national animal' and appears on the new currency. First priority has been given to improving the 1000 -sq- $\mathrm{km}$ Sunderbans reserve, created a few years ago, where there are about 100 tigers and, because the swamps are subject to tidal flooding, almost no human settlements. Elsewhere in Bangladesh tigers have disappeared, apart from a few vagrants in the Chittagong Hill Tracts and northern Sylhet.

To summarise, saving the tiger from extinction has now become a multi-national co-operative project. India, Nepal, Bhutan and Bangladesh between them are creating fourteen expertly managed reserves specially suited to the tiger's ecological requirements, and eighteen countries with WWF national appeals are raising money for them. If sufficient funds can be raised for staffing and equipping them to the highest standards, so that viable breeding populations can be maintained, this spectacular species may yet be saved.

\section{Reports and Journals}

The East African Wildlife Journal Vol. 9 includes papers on elephant ecology in the Queen Elizabeth park in Uganda by Field, a comparison of four crocodile populations by Watson, Graham and Parker, food habits of the lesser kudu in the Tsavo by Leuthold, utilisation of mineral licks by game in the Yankari in Nigeria by Henshaw and Ayeni, and a bibliography relating to the ecology and energetics of East African large mammals by Peterson and Casebeer.

Barren-ground caribou are the subject of four publications by the Canadian Wildlife Service (Ottawa): Food Habits of Wolves on Barren-Ground Caribou Range, by E. Kuyt (\$1), Biology of the Kaminwriak Population $(\$ 1.50)$, and Distribution of Barren-Ground Caribou harvest in northcentral Canada (\$1), both by G. R. Parker.

The Biology and Behaviour of the Reedbuck in the Kruger National Park by Hartmut Jungius (Paul Parey, Hamburg), is the result of a 13-month study in $1967 / 68$, one objective of which was to investigate this antelope's habitat requirements and so contribute to its effective conservation.

Project Aqua by H. Luther and J. Rgosta, IBP Handbook No 21 (Blackwells, £2) documents briefly some 650 aquatic sites-lakes, rivers and wetlands-proposed for conservation.

The Pedigree Book of the Przewalski Horse edited by Dr Jiri Volf, the studbook keeper, shows that on January 1, 1972, there were 85 stallions and 111 mares in captivity; 23 foals were born during the year and 10 horses died. 